\author{
Ogihara Hirotoshi \\ Ching Chao-jung
}

\title{
SI 3656 and other Kuchean tablets related to the Kizil grottoes in the St. Petersburg Collection*
}

Abstract: This paper introduces five wooden tablets written in Kuchean (Tocharian B) and kept in the Institute of Oriental Manuscripts, Russian Academy of Sciences (IOM, RAS), namely SI 3656 (SI P/136в), 3669 (SI P/139д), 6385 (SI Strelkov-D/3), 1931 (SI Strelkov-D/51) and 6456 (SI Strelkov-D/85). THT4063, an unedited tablet kept in Berlin, the text of which is largely parallel with SI 6456, is also introduced here.

According to the joint authors' investigation, which has been ongoing since 2009, these tablets are economic and administrative documents, and some of their features are comparable with the Kuchean sale contract THT4001. The severely damaged SI 1931 is particularly valuable because it proves that three currencies circulated in pre-Tang Kucha. Together with THT4063, the other four tablets are closely related to the Yurpasșa Monastery, which is repeatedly mentioned in the findings from the Kizil grottoes as well as the graffiti surviving there. Therefore, the content of these tablets helps scholars to restore the history of this important Buddhist site as well as the activity of foreign expeditions in Chinese Turkestan.

Key words: Kucha, Tocharian, Kizil, Buddhism, Central Asia

\section{Introduction}

Since Sylvain Lévi's correspondence with Sergei F. Oldenburg, Nikolai D. Mironov and other Russian scholars, the importance of the Tocharian materials kept in the Institute of Oriental Manuscripts, Russian Academy

(C) Ogihara Hirotoshi 荻原裕敏 (Associate Professor, Hakubi Center, Graduate School of Letters, Kyoto University)

(C) Ching Chao-jung 慶昭蓉 (Postdoctoral researcher, Centre de recherche sur les civilisations de l'Asie orientale, Paris / International Research Fellow, Japan Society for the Promotion of Science-Kyoto University)

* We would like to express our most sincere gratitude to Prof. Irina F. Popova and other colleagues at the the Institute of Oriental Manuscripts, Russian Academy of Sciences for their kind hospitality since our first visit in 2009. Many thanks are also owed to the Turfanforschung, Berlin-Brandenburgische Akademie der Wissenschaften and the Staatsbibliothek zu Berlin, which have permitted our investigation of the wooden tablet THT4063 since 2008. 
of Sciences (IOM, RAS) in St. Petersburg has been widely known. ${ }^{1}$ After the investigation led by Dr. Margarita I. Vorobiova-Desiatovskaia in the 1990s, Tocharian manuscripts in the Russian Collection have been largely identified. ${ }^{2}$ Therefore, Prof. Georges-Jean Pinault published several Kuchean (i.e. Tocharian B) secular documents in $1998^{3}$ and Dr. Klaus T. Schmidt was expected to publish more texts. ${ }^{4}$ In addition, Douglas Q. Adams $(2000,4)$ provided Pinault's provisional revision of the Kuchean tablet SI P/139(d) (i.e. SI P/139д) that was published by Lévi (1913, 320 n. 1), ${ }^{5}$ and Schmidt (2001b) analysed a bilingual Kuchean-Prākrit tablet SI P/141 together with two similar ones (THT4059 and THT4062) kept in Berlin. ${ }^{6}$ Since 2002, Pinault has revised the reading of the Buddhastotras $\mathrm{SI} \mathrm{P} / 1 \mathrm{~b}$ and $2 \mathrm{~b}$ in addition to the Sanskrit-Kuchean glossary SI P/65b 1+2 previously published by Dr. V.S. Vorobiov-Desiatovskii (1958). ${ }^{7}$ Melanie Malzahn (2007a: 93) also read SI M-TD/31b in the Malov Collection according to a photograph published by Wilfried Seipel (1996: 345).

During our first visit to the IOM, RAS (March 21 to 12 April 2009), we were provided with a list of new SI numbers, which were still a work in progress. It is largely comparable to Pinault's hand-written list of old SI numbers made in 1998, which he kindly communicated to us in autumn-winter 2008. But a few numbers seemingly escaped from his early investigation, including the tablet SI 3656 (SI P/136B) to be treated in this paper. ${ }^{8}$

The text of SI 3656 is faint, but its features are similar to those in the contract of sale HT4001. ${ }^{9}$ Like THT4001, SI 3656 is also related to the Yurpusșka Monastery. As argued in our edition of THT4001, Yurpusşka is the

${ }^{1}$ For example, see Mironov 1909; LÉVI 1913: 320 and BongARD-LEVIN et al. 2002: 123141. For a more complete review of the studies of the Tocharian manuscripts kept in St. Petersburg in the last century, see MALZAHN 2007a: 91-93 and VorobIOVA-DESYATOVSKAIA 2008: 72-73.

${ }^{2}$ See Vorobiova-Desiatovskaia 1997; Vorobiova-Desiatovskaia 2006.

${ }^{3}$ I.e. SI B Toch./9, 11 13 and SI P/117.

${ }^{4}$ Cf. Vorobiova-Desiatovskaia 1997: 210. The five pieces published by Pinault (1998) are also partially mentioned by Schmidt (2001a).

${ }^{5}$ See infra, $\S 4$.

${ }^{6}$ Ching (2013a) gives a reinterpretation of the three tablets as receipts of tax payment.

${ }^{7}$ See Pinault 2002a: 274-276 (SI P/2b); Pinault 2008: 293-311 (SI P/1b and P/2b) and PinAULT 2002b (SI P/65b 1+2).

${ }^{8}$ It seems that at a certain stage, the SI 3655 (SI P/1366) and 3656 (SI P/136в) were confused or counted together. The former was partially transliterated by Pinault in 1998, and the full content of this tablet was read by Ching (2010: 324-326).

${ }^{9}$ See CHING and OGIHARA 2012. 
ancient name of a district around the Kizil grottoes or the general name of the whole area. The Kuchean documents kept in the IOM, RAS preserve abundant attestations of this name, and they are the most valuable first-hand material for the study of the early history of this region.

\section{SI 3656: Formal description}

The tablet SI 3656 measures $27.0 \mathrm{~cm}$ in width and $13.1 \mathrm{~cm}$ in length. The upper-left corner of the recto side is largely broken. Both sides are written in Kuchean.

As indicated by the old signature SI P/136B, the tablet once belonged to the Petrovskii collection. ${ }^{10}$ The round blank in the centre of the recto can be found on several Kuchean tablets, such as the sale contract (THT4001) and the three bilingual tablets (SI P/141, THT4059 and THT4062) mentioned above. On the central blank of SI 3656, traces of greyish clay used for sealing can be seen. The V-shaped incisions on its four sides are also similar to THT4001, the three bilingual tablets and the well-known laissez-passers found by Paul Pelliot. Therefore, the original binding of SI 3656 may resemble the model we have suggested for THT4001:

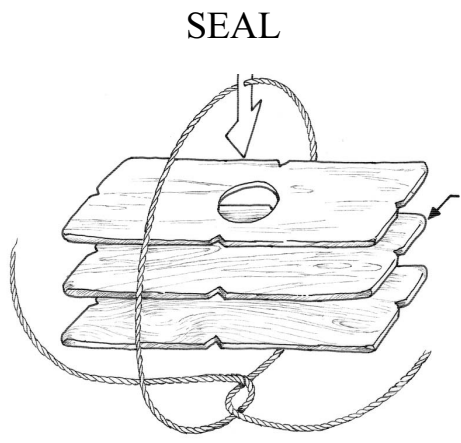

SI 3656

Among the tablets treated below, SI 6385 and THT4063 preserve one and four V-shaped incisions, respectively, although it is uncertain whether there are central round blanks due to the poor condition of these two tablets.

\footnotetext{
${ }^{10}$ For N.F. Petrovskii's activities and contributions, see VorobiovA-DESIATOVSKAIA 2004; PopOVA 2008a: 25; and PopOVA 2008b: 148-150.
} 


\section{Translation of SI $3656(=$ SI P/136B) (see the transliteration on p. 48) ${ }^{11}$}

$1 / / /$...(is) being in the year of...(?). (At) this moment ///

2 /// (something) [has been done]... (In) the Yürpașka [Monastery]... ///

3 /// (The ones being) present in..., the novice monk called Punyayaśe...

4 /// ...thus (these are namely) we. We two are subject to... ///

$5 / / / .$. they torment and harm us ///

$6 / / /$ For [this] reason, we two thought thus: 'The $O \mathrm{Oo}_{u}$-official ${ }^{12}$ was dwelling (here). ... legal dispute(?) agreed(?) with Mānäkke... ///

7 ...He could bring the Samgha (of) this monastery to our life (lit. 'He could give us this monastary-samgha in existence'). Then we two ourselves

8 We discuss the giving of...' Forever in the future, with this document(?) ${ }^{13} \ldots$ together with... ///

9 ...they are not to be claimed by anyone [else] nor should be [inquired about] (by anyone else). As in this monastery...///

$10 / / / \ldots \wedge$. May our monastery be the refuge(?)... ///

b

$1 / / /$ of/to Punyayaśe... V ...from this moment on(?)... ///

2 ///..., Püñyavräddhi the Ärañye, ...the Agamadhāre, ...

3-8 [untranslatable]

${ }^{11}$ The conventions generally follow the principles set up by E. Sieg and W. Siegling:

\section{Transliteration}

[ ] partly damaged akșara(s). I// damaged edge.

() seriously damaged akșara(s) of which - an indeterminable akșara.

the reading is partly or totally restored. - indeterminable part of an akșara.

Transcription: Fremdzeichen and viräma in the transliteration are ignored. When necessary, restoration based on the knowledge of the Tocharian manuscripts is adopted. Proper names and titles/positions are indicated with capitals.

Translation: The usage of brackets and parentheses follows that of the transliteration. The brackets indicate the damaged text, of which the uncertainty of reading should be kept in mind, and the parentheses indicate our restoration or interpretation based on seriously damaged text.

${ }^{12}$ This official title/position is attested in THT4001, which Ching related to Niya-Prākrit Ogu and a later form Akau in Kuchean (see CHING and OGIHARA 2012: 112-113). It appears as Okau in SI 6385 and THT4063 (see infra).

${ }^{13}$ The word parso as used here is interesting. It is usually understood as the Kuchean word for 'letter', but from the context, it seemingly means 'document' here. 


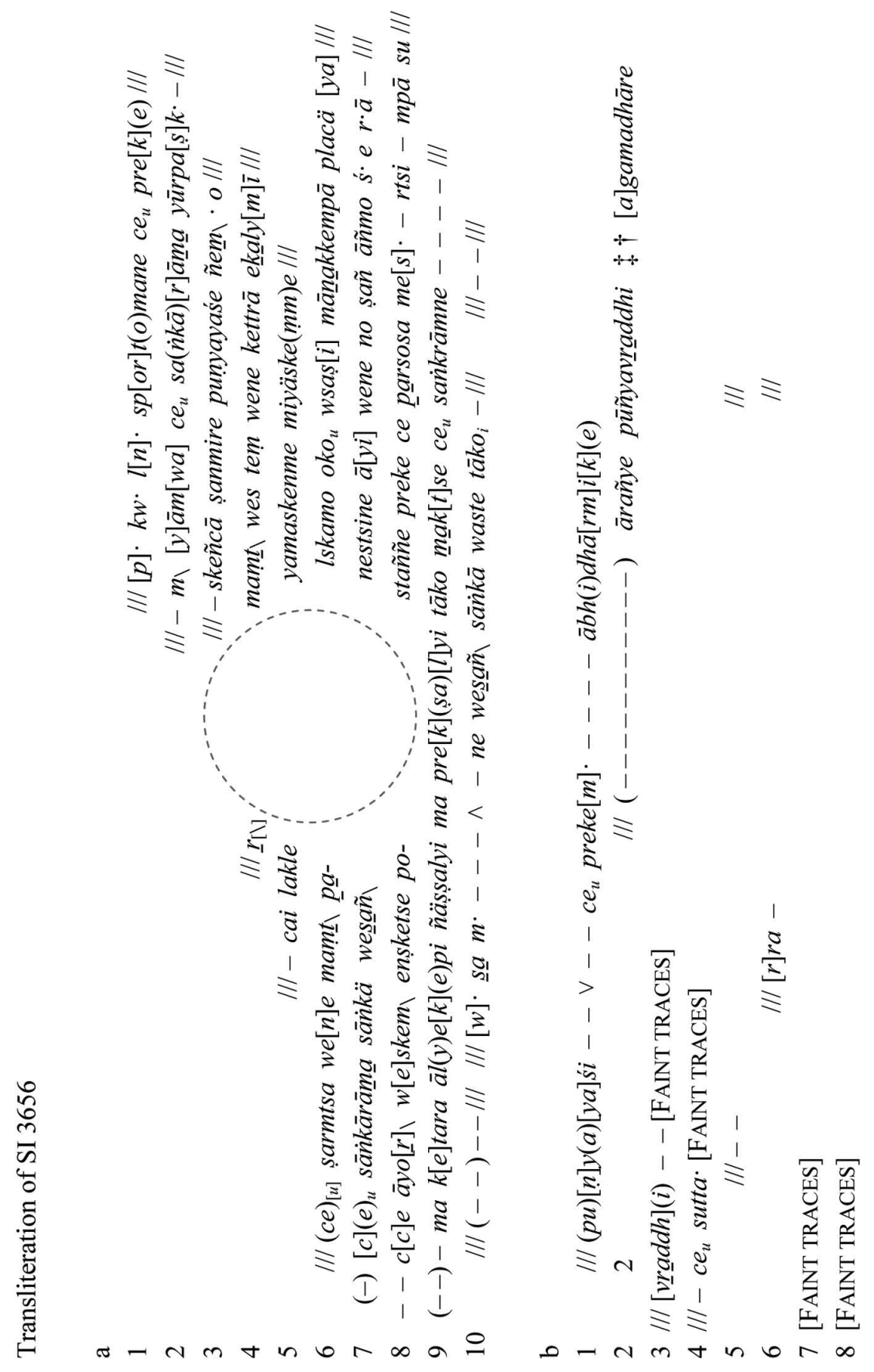




\section{Notes on transliteration}

a1 $\quad[\boldsymbol{p}] \cdot \boldsymbol{k} \boldsymbol{w} \cdot \boldsymbol{l}[\boldsymbol{n}] \cdot:$ Possibly to be restored $p(i) k w(\ddot{a}) \ln (e)$.

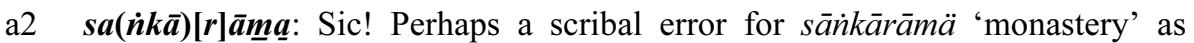
attested in a7.

Yūrpa [ș]k /// : We intend to restore Yürpaṣk(aine) 'in Yürpaṣka' here.

a3 - skeñ $\overline{\boldsymbol{a}}$ : To be restored ( $\underline{\text { ma }}$ ) skeñ $\bar{c}$.

$\tilde{\boldsymbol{n} e \underline{\boldsymbol{m}}} \backslash \boldsymbol{o}$ : It is possible to restore $\tilde{n} e m(m) o$ with the so-called bewegliche $-o$ in Kuchean.

a4 ekaly $[\boldsymbol{m}] \overline{\boldsymbol{i}}$ : Alternatively to be read ekaly[mi].

a5 cai: It is also possible to read rcai.

a6 $\boldsymbol{y} \boldsymbol{a}$ ///: Perhaps a form of yām- 'to do'.

a $\boldsymbol{t} \overline{\boldsymbol{a}} \boldsymbol{k o}$ : Scribal error for $t \bar{a} k o_{i}, 3 \mathrm{sg}$.opt. of nes- 'to be'.

mak $\underline{k} \boldsymbol{t}] \mathbf{s e}$ : Scribal error for mäkte 'as'.

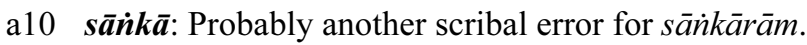

b1 /// $-[\tilde{\boldsymbol{n}}] \boldsymbol{y} \cdot$ : Perhaps to be restored (āra) $[\tilde{n}] y(e)$.

preke $[\boldsymbol{m}] \cdot$ : It is uncertain if one can restore prekem(em), abl. sg. of preke 'time' here.

\section{Textual features of SI 3656}

In SI 3656, the ductus of $<\underline{\text { ma }}>$ and $<\underline{\text { na }}>$ shows an archaic phase as those attested in B133 (THT133) indicated by Malzahn (2007b: 297). From a linguistic point of view, these are also archaic:

$\begin{array}{ll}\text { Forms attested in SI } 3656 & \text { Classical forms } \\ \text { mäskeñcā } & \text { mäskeñca } \\ \text { kettrā } & \text { ketara, etc. } \\ \text { ekälymī (or: ekälymi) } & \text { ekalymi } \\ \text { pälskamo } & \text { palskam } \\ \text { mānäkkempā } & \text { *manakkempa } \\ \text { placä (obl.) } & \text { plāc } \\ \text { pärsosa } & \text { parsosa } \\ \text { ālyekepi } & \text { alyekepi } \\ \text { ārañye } & \text { arāñye }\end{array}$

However, forms that should be classified as belonging to the classical stage also appear, e.g. sportomane, șarmtsa, șañ, postaññe, ketara and so on. This leads one to think that SI 3656 was not written in the archaic stage, but at a later time under the influence of an older model text; thus, when the 
formulae were copied, some archaic features were retained. Content highly comparable to the sale contract THT4001 is given as follows:

\section{THT4001a9}

e[nșk]etse postäñ $[\tilde{n}]$ e preke mā ketra alyekepi ñäsșälle $m[\bar{a}]$ prekșälle tako ${ }_{i}$.

Forever in the future, he (i.e. the sold person) should not be claimed by anyone else nor should be inquired about (by anyone else).

\section{SI $3656 \mathrm{a} 8$}

enșketse postaññe preke... 'Forever in the future...'

\section{SI $3656 \mathrm{a} 9$}

...[mā] $k[e] \operatorname{tara} a \bar{a} l(y) e[k](e) p i$ ñäsșalyi ma pre(kșä) [l]yi tākoo $o_{(i)}$.

...they are [not] to be claimed by anyone [else] nor should be [inquired about] (by anyone else).

The phrases $c e_{u} \operatorname{preke(ne)~'(at)~this~moment'~(a1!),~}{ }^{14} c e_{u}$ sarmtsa 'for this reason' (a6!) and mäskeñcā 'being present (somewhere)' (a3!) are also used in THT4001, and they seem to be typical expressions in official and civil documents. The name list in SI 3656b2-3 also resembles the list of witnesses in THT4001 in the sense that several monks with the title of Araññe 'forestdweller', Agamadhāre 'Ägama-holder', etc. are found in the latter; thus, at first glance, SI 3656 appears to be another sale contract. Nonetheless, no price or payment is mentioned. Therefore, it is safer to see SI 3656 as a document that allowed refuge sought by two persons, namely the novice monk Punyayaśe and his partner, whose name and identity were lost. Because of some unpleasant incident (a5), they decided to quit their original identity and requested the $\mathrm{Oko}_{u}$-official's permission to move to the Yurpūsska Monastery. In particular, if our restoration of mäskeñcā (a3) is plausible, these two persons are very likely the active party in this process of application because the two sellers in THT4001 are introduced by the first person (nom. pl. wes) after the word mäskeñca just before expressing their will to announce the sale.

In this case, Punyayase and his partner may have asked to become novices in the Yurpāṣka Monastery. We are unsure whether waste 'refuge' (a10) is a rhetoric expression or has a legal implication (e.g. obtaining financial or

${ }^{14}$ The aksara on the right of preke does not remain. Whether the locative suffix ne was written or not, the comparability between the two tablets is evident. 
juridical support from the authorities or the Yurpāṣka Monastery). At any rate, the damaged content reveals that the authorities agreed to their request, and this document was written in presence of several witnesses, including the monk Pūñyavräddhi and his colleague(s).

Buddhist disciplines support this view. A rule widely found in the vinaya texts states that the samgha should not recruit a new member who is someone's slave or servant. For example, the Chinese Sarvāstivādin Vinaya says:

從今奴大家不放, 不應與出家。若與出家, 得突吉羅罪。15

From now on, one should not let a slave/servant to be ordained without his owner's permission. If such a slave/servant is ordained, one convicts the duṣkrta sin.

According to the karmavācanā belonging to this school that is to be spoken on the occasion of a monk's ordination, the samgha should ask him a series of questions:

汝丈夫不。年滿二十未。非奴不。不與人客作不。不買得不。不破得不。 非官人不。不犯官事不。不陰謀王家不。不負人債不。...16

Are you male? Are you over 20 years old? Are you not a slave/servant? Are you not hired by someone? Have you never been bought by someone? Have you never been forcibly owned by someone (because of invasion, etc.)? Are you not a slave/servant working for the government? Are you free from any criminal conviction? Have you never been traitorous to the royal family? Do you bear no burden of debt?

Thus, it is reasonable to suggest that the purpose of SI 3656 is to authorize the change of the civil identity of the two applicants. It seems, at least, that the novice monk Punyayase was allowed to move into the Yurpāṣka Monastery. In pre-Tang Gaochang (today's Turfan), the population was mainly classified as either 'lay' (俗 sú) or 'monastic' (僧 sēng for samgha). This classification involved a distinction between the monastic population and lay people in terms of taxation and labour services. We do not know whether the pre-Tang Kucha also classified its people into these two categories, but one can imagine that in such a 'Buddhist' country, some procedure may have existed to certify one's entrée into a monastery or movement from one monastery to another to avoid administrative problems. If this interpretation is plausible, SI 3656 implies the official registration of monks and novices in Kucha. More investigation is necessary to understand the control of the mo-

\footnotetext{
${ }^{15}$ Taishō vol. 23, no. 1435, juan 21, p. 151 c28-29.

${ }^{16}$ Taishō vol. 23, no. 1435, juan 21, p. 156 a28-b2.
} 
nastic population in this powerful oasis state on the eastern branch of the Silk Road.

\section{Yurpāska: the possible finding spot of SI 3656}

As mentioned above, the district of Yurpāṣka is located approximately at today's Kizil grottoes rather than in Yanqi (around $300 \mathrm{~km}$ in the east of Kucha). Several tablets tagged with MQ (ming-öi Qizil) in the Berlin collection attest this toponym, including THT4001, THT4059 and TS43. ${ }^{17}$ Recently, we examined more graffiti surviving in situ that strongly supports the identification of the Yurpasska Monastery with the grottoes. ${ }^{18}$ Consequently, the finding spot of SI 3656 is very likely Kizil as well, although its site signature is lost. For the same reason, the tablet initially published by Lévi (1913), through a collaboration with S.F. Oldenburg, is possibly from Kizil, too. Here is our revised reading: ${ }^{19}$

SI $3669=$ SI P/139д

a

1 śak $\underline{k}_{(\backslash)} k s \underline{[}[e] k s \underline{u} u(m) t s a$ swarnāaūsp̣pe lānte $[k s ̣ u](m n e) / / /$

$2[y$ cau $] w^{\ddot{a}} \backslash$ preke yurpāṣkai sañkrāmne máskeñca sa ///

3 purṇasssä $\tilde{n}[e] \underline{m}^{a ̈} \backslash$ śamaśk[em] tsukalememn ${ }^{\ddot{a}} \backslash \underline{\text { tarkāte }}$ tum $[$ ts $]$ e ///

4 akeñe ypoyä ${ }^{\ddot{a}}$ moko nañiște

1 In the eleventh regnal year, [in the reign] of the king Swarnābu ụpe, //I

2 ...(At) [that] time, ...being present in the Yurpāsska Monastery, //I

3 (sb.) let a [boy] called Purnāásä leave from (his) nurse(?). ... of it... ///

4 Nañiște, Prefect of the Frontier (Prefecture).

$\mathrm{b}$

1 kaw $[o] t s i n ̃ e e^{20}$ yaśotarkontse soyä larașk(e)

2 purnakki procen $\backslash$ purnakșeme

3 ștakule

4 atsiñe yoniyatse śiñcake sutasomi proce [ $[\underline{]}]$

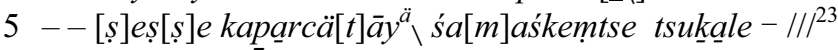

${ }^{17}$ See Ching's review and arguments in CHING and OGIHARA 2012: 106.

${ }^{18}$ See OgIHARA 2013 and Xinjiang Kucha Academy et al., 2013b.

${ }^{19}$ Based on CHING 2010: 327-329 with slight modification.

${ }^{20}$ Or: kaw $\left.\underline{\text { li }}\right]$ tsiñe.

${ }^{21}$ One may also read śātuma[p]·///.

${ }^{22}$ One may also read $p i \cdot[c] \cdot / / /$

${ }^{23}$ This line is faint and difficult. The akșara following tsukale may be $k \bar{a}$. 
1 Larașe, son of Yaśotarko* (being inhabitant?) of Käw [o] tsi*.

2 Purnakșeme, brother of Purnakke*

3 Sțtakule.

4 Śñcake of the *Ātsi district(?) ${ }^{24}$ brother of Sutasome*.

5 ..., nurse of the boy Kapärcätāy of (some region/clan) $/ / /^{25}$

As indicated by Lévi, this tablet was written during Suvarnapuṣpa's reign (?-624CE). We have pointed out that the expression akeñe ypoy ${ }^{\ddot{a}} \backslash$ moko does not mean 'the country-elder of the Agnean kingdom' but the prefect of a prefecture near the border of Kucha, possibly not far from the Kizil grottoes. $^{26}$ In addition, we read śak $\underline{k}_{(\backslash)} k s[e]$ 'eleven' (a1) instead of $p[i] \underline{k} \backslash k[c] e$ 'fifth', $[y c a u] w^{\ddot{a}} \backslash(\mathrm{a} 2)$ instead of $c a u w^{\ddot{a}}$ and purṇāśä (a3) instead of purṇāyä. These modifications permit us to improve the translation.

Thanks to Pinault (p.c. April 2009), the hapax tsukäle may be regarded as the gerundive of tsuk- 'suck, suckle, etc.', and the monastery may have operated an orphanage. Inspired by this idea, we see tsukäle as 'nurse, wet nurse ${ }^{, 27}$ and perceive side a of SI 3669 as the prefect's permission for someone in the monastery to take the boy Purṇāśä from his nurse. In other words, this tablet is probably an official document of adoption. Strictly speaking, an orphan is a child whose parents are dead, but the broken text of SI 3669 does not state whether the boy's parents are alive. Henceforth, one cannot exclude other situations, e.g. his parents had donated themselves to the samgha, leaving their child in the care of their relatives. Interestingly, the Chinese Sarvāstivādin Vinaya regulates that a lay Buddhist should not enter the samgha simulataneouly together with his own child, if the child is under 15 years old, because such an act will cause rumours of intermarriage between monks and nuns. ${ }^{28}$ Given that the Sarvāstivādin school was deeply influential in Ancient Kucha, part of its population may have gone into the monastic world generation by generation at a certain stage of their lives.

Another tablet SI 6385 also attests the name of Yurpāṣa. Our transliteration is as follows:

\footnotetext{
${ }^{24}$ yoniya is probably a variant of yoñiya, which most likely means a kind of administrative district in rural areas (see OGIHARA 2009: 385, 287 and CHING 2013b: 70-72).

${ }^{25}$ An alternative translation is 'Kapärcätāy of (some region/clan), the boy's nurse'. In this case, the nurse is a male, as revealed by the adjective masculine form ${ }^{o}$ ss $e$.

${ }^{26}$ See ChING and OgiHARA 2012: 106; Ching, forthc.

${ }^{27}$ CHING 2010: 328.

${ }^{28}$ Taishō vol. 23, no. 1435, juan 21, p. 151b4-22. In the following paragraph, the limit is tolerated as under seven years old.
} 
SI 6385 (= SI Strelkov-D/3)

(a)

$1(--)-\tilde{n} a y \backslash e \tilde{n} c(i) \underline{l}^{(\ddot{a})}-[s] \cdot(\cdot)[k] \cdot[k] \cdot[\tilde{n}] \cdot k_{(u)} s^{\prime}--^{29}------/ / /$

2 - aits $(i)$ tun $\underline{-}$ - [we]s a ompek patalakșane ${ }^{30}$ yurpașka ///

$\left.3-p a[l] k e_{\text {se }} \overline{\tilde{n} e \underline{m}} \backslash c i[\underline{m}]\right]^{(\ddot{a})} \cdot \cdot e[m]^{31}\left(k_{u} s \dot{a}\right) n e m(t)[s]$ a piśaltse ce $(m)$ wantare $[s] a / / /$

$4 \quad / / / \cdot e / / / \quad / / /-----\wedge$

1 ...(a kind of tax or duty?) imposed on... [k $k_{u}$ śāne $] . . . / / /$

2 to give... [we] right there in Patalakșa ..., Yurpāṣka... ///

3 ...(sb.) called Palkeśe ...[is able](?)... (valued) at five thousands $k_{u} s$ ánes. Because of this affair, ///

4 [untranslatable]

(b)

$1-\cdot \operatorname{or}(\backslash)^{32}$ yamașa : ce $e_{i}($ e)mi takare okau $\vee[$ sa $] \dot{n k u l}[e] / / /$

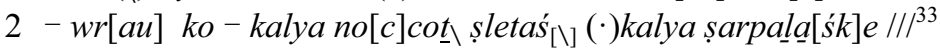

1 He made a (purchase?). These witnesses were (Sankule) the Okau-official, ///

2 ...Wrau... Sletaś-official... [untranslatable]

The ductus can be classified to Malzhan's standard script. Linguistically, the text shows a few archaic features, e.g. Yurpașka ((a)2, class. Yurpāṣka), wantäresa ((a)3, class. wäntaresa) and takare ((b)1, class. takāre). Nevertheless, there is at least one form placed in the classical stage, namely piśältse in (a)3, due to an allegro pronunciation of piś yältse 'five thousands' as noted by Peyrot (2008: 128-129).

The remaining context does not permit us to determine the exact purpose of this document. It may be some kind of official document or contract, in which the currency of $k_{u}$ s'ane 'Kuchean coin' is attested in many wooden documents. For example, the price given in the contract THT4001 to buy a young man or boy is $18,000 k_{u}$ śanes. Given that the sellers in THT4001 (i.e. the party who took the initiative in the transaction) are expressed by the

\footnotetext{
${ }^{29}$ To be restored a form of $k_{u}$ śāne.

${ }^{30}$ Locative of patalaksa*. This proper name is seen in Ot.12.14 as the stem of an adjective patalakșāsșe*.

${ }^{31}$ The form $\operatorname{cim}(m p)$ em (= cimpem), 3.pl.prs. of cämp- 'to be able to' may be restored here, although this form is usually classified to the late stage (cf. Peyrot, 2008: 55-57).

${ }^{32}$ Perhaps (kary)or* 'buying'.

${ }^{33}$ The word segmentation of this line is uncertain. The hapax no[c]cot (a personal name?) may be a variant of nocot 'deposit(?)'. Another hapax kalya may be related to an identity or an official title kalyä that is seen in THT4001.
} 
first-person plural, there is reason to suggest that the wesä 'we' in SI 6385(a)2 indicates the active party of a deed, of which some socially important persons including an $\mathrm{Oko}_{u}$-official called Sankule were present as witnesses (remi).

The IOM, RAS possesses another important tablet concerning currencies in Ancient Kucha, which is thus far the only piece of secular document attesting the local circulation of gold coins ( $\operatorname{tin} \bar{a} r^{*}<$ Buddhist Skt. dināra-):

SI $1931($ SI Toch 1931) $=$ SI Strelkov-D/51

(a)

\begin{tabular}{|c|c|}
\hline $1 / / /$ & 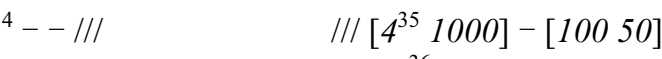 \\
\hline $2 / / 1$ & $/ / /[10000]^{36} 61000810050$ \\
\hline $3 / / /$ & eneśs $[n] e\left[k_{u}\right] \dot{s}[\bar{a}]$ ni $2[10000]-[10005100]-$ \\
\hline $4 / / /$ & paiykānt $[s]$ aṃ cānem $k a[m] \bar{a}(n t)[e$ 3] - - /// \\
\hline $5 / / /$ & $y[u] s a^{37} c \bar{a}[n](e) m$ wsam $\underline{\backslash} 10005--/ / /$ \\
\hline
\end{tabular}

(b)

$1 / / /[l y](i p \bar{a} r)\left[e k_{u} \dot{s}\right](\bar{a}) n e m n t s a 21000310040$

2 III $\cdot[a u]-$ tināranta $\left.3[c] \bar{a} n[i] 3^{-38} \cdot s \cdot{ }^{39}-\operatorname{trau} \underline{k} \underline{a}[t t]\right]^{40}--(k)_{[u]} s^{s}(\bar{a} n i) 91000$ 81006

$3 / / / 1000[2] 100(--)$

SI 1931 is thus far the only piece of secular document attesting the circulation of gold coins in the pre-Tang Kucha. Both the script ductus and the language appear quite standard, although a closer reading must be done after infrared photography. Because the text is extremely faint and the figures are mostly broken, its full translation cannot be determined at this stage. Nevertheless, the readable parts look very interesting. Some fixed expressions have been found from other wooden documents, e.g. postanontä 'later, latter', eneś[n]e $\left[k_{u}\right] \dot{s}(\bar{a}) n i$ 'Kuchean coins in cash(?) ${ }^{41}$ and the verbal form

${ }^{34}$ Or $[p] u$.

${ }^{35}$ Or [5].

${ }^{36}$ For more on the difference between the figures 10000 and 100, see CHING and OGIHARA 2012: 108.

${ }^{37}$ Or $y[u] s[a i]$.

${ }^{38}$ Possibly [100] or [10000].

${ }^{39}$ Perhaps to be restored wsam $\backslash$.

${ }^{40}$ To be read either $[t t] \cdot$ or $[n t]$.

${ }^{41}$ For more on the Kuchean term for 'cash', see CHING and OGIHARA 2012: 108. 
lyipāre '(somethings) remained' as the expression for 'balance' in Kuchean accounting. Interestingly, this tablet records a payment to a group of painters or calligraphers (paiykānt [s]am < pik- 'write, paint'), which is meaningful to interpret the development of Kuchean art. The word paikāntsa* ' \pm painter, calligrapher' was previously only seen from a wall inscription in Kizil Cave No. $181 .^{42}$ Its attestation in SI 1931 is the first in Kuchean documents.

SI 1931 is thus far the only piece of secular document that attests multiple currencies in Ancient Kucha, and three kinds of money are indicated: cāne* '(Chinese?) coins', $k_{u}$ śāne* 'Kuchean coins' and tinār $r^{*}$ 'gold coins'. It is still difficult to identify them as various archaeological types of unearthed coins, but at any rate, SI 1931 supports Xuanzang's depiction of Kucha that 'the currencies are gold coins, silver coins and small copper/bronze coins' ${ }^{43}$ In this regard, SI 1931 is one of the most valuable documents for historians of Chinese Turkestan.

\section{SI 6456 and THT4063: a series of reports?}

Soon after our first visit to IOM, RAS in 2009, the parallelism between THT4063 and SI 6456 (Strelkov-D/85) came to our notice. The condition of the wooden tablet THT4063 is better, so it is useful for restoring some damaged parts of SI 6456.

As revealed by its site signature (T III MQ 212), THT4063 was found at the Kizil grottoes by the third German expedition. It is also a document about the Yurpasșka Monastery. This name is not preserved in SI 6456, but both THT4063 and SI 6456 mentioned a person called Tarmatāse (<Skt. Dharmadāsa-, lit. 'slave/servant of the Law'). Therefore, they likely concern the same monastic community. The remaining text of SI 6456 is almost perfectly parallel to THT4063. The only difficulty is a broken passage near the beginning of SI 6456, namely $s \cdot l t \cdot-\dot{s} c o---($ line 1$)$, which should correspond to THT4063a1 $--[l e]---[$ ntso $k] \cdot$; however, different content is probably involved. In addition, the broken texts șamāne /// 'monk' (line 1) and ekita /// 'help' (line 2) found in the upper-right margin of SI 6456 may be useful in restoring the lost part of THT4063.

\footnotetext{
${ }^{42}$ Attested as pl.com. pai $[k] \bar{a} m$ țämpa, see Xinjiang Kucha Academy et al. 2013a: 345.

${ }^{43}$ CHING and OGIHARA 2010: 102 n. 56.
} 
THT4063 (The passages matching SI 6456 in bold)

a

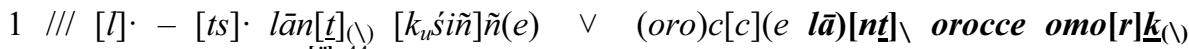

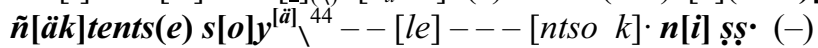

$2 m \bar{a}-/ / / / / /$ - yurpā $[s]($ kai sañk $) r(\bar{a})[m n](e) w[r] \cdot-\cdot[a i \quad s a] \dot{n} k a---\cdot[i]---[l y] \cdot$

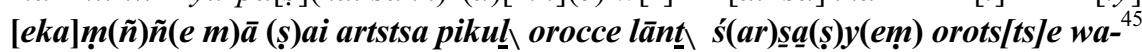

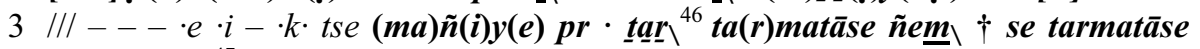
lantañ̃̃ana ${ }^{47}$ pre-

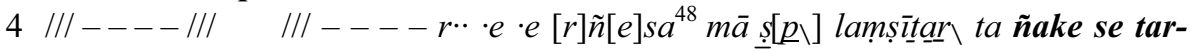
matāse pkāte pi[ku]l[s] $]$ e(m) $k_{u}$ śānem wiltse yurpāṣka-

5 III șsai e $(k)[s](a) l y[i] m-/ / I \quad / / / \quad l \cdot-\ldots$ $p[u] t[t a] t \bar{a}[s]$ i yärșal $[\tilde{n}]$ esa c [ e p $]$ ete - tarmatā-

$\mathrm{b}$

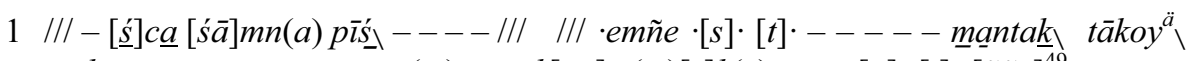
makte ce parsone omsame $(m)$ papek $[a u] e(m)[s] k(e) t s t s e ~ p[o] \cdot[t] \cdot[\tilde{n} \tilde{n} e]^{49}$

2 III $\cdot r \cdot k e$ okau sañkai $[\bar{s}] e[\bar{a}] k s(a)[s] u--[p](a i)[k a]+$

a

$1 / / /$ the king of ..., [the great king of Kucha], son of the great Omork* god/majesty, ...///

${ }^{44}$ Here, the passage $[l] \cdot-[t s] \cdot \operatorname{lān}\left[t K_{u} \sin \tilde{n}\right] \tilde{n}(e$ oro $) c[c](e \quad l \bar{a})[n t]$ orocce Omo $[r] k$ $\tilde{n}(\ddot{a}) k t e n t s(e) s[o](y)$ contains a series of epithets of a certain Kuchean king. Strikingly, to relate Kuchean kings with Omork* is only attested on these two tablets. Omork* seems to be either a deity, a foreign sovereign('s title?) or a toponym. Its variants and derivatives are attested in THT2994, SI B Toch./11 and PK L.C. XXXVI, etc., cf. CHING 2010: 398-399.

Incidentally, the expression ñäktemts soy 'son of gods' that Winter (1963) claimed to have read in a Prākrit-Tocharian B bilingual document kept in Berlin and understood as a transposition of Skt. devaputra- is thus far not been found among the bilingual tablets kept in Berlin. In THT4063 and SI 6456, the text evidently reads ñäktentse (sg. gen.) instead of ñäktemts (pl. gen.). If Winter's reading is reliable, what he studied may have been lost after he published his paper.

${ }^{45}$ To be restored walo 'king' together with the beginning of the next line.

${ }^{46}$ To be restored pretär following its counterpart in SI 6456. It is probably a verbal form, although providing a satisfactory solution is difficult. We temporarily take it as the 3sg.mid.prs. of pär- 'to carry, bear', of which the ideal form should be *partär. It may be an analogical form influenced by premane or preñca, which has -e- as a thematic vowel; alternatively, the class III of the present system may have influenced this root.

${ }^{47}$ The f.pl.nom./obl. of lantaññe*. This feminine form is not registered by Adams (1999; 2013) or Thomas (1964), but it is seen in PK NS 63a3: $l[a](n) t[a] \tilde{n} \tilde{n} a[n a] k l a i(n a)$, lit. 'the king's women', cf. OGIHARA 2009: 305-306.

${ }^{48}$ Perhaps to be restored $(p) e(r n) e[r] \tilde{n}[e] s a$.

${ }^{49}$ To be restored $p[o](s)[t](a)[\tilde{n} \tilde{n} e]$. 
2 /// ...(in) the Yurpāṣka (Monastery)... [a monastery... it was not a possession... Each year, they informed] the great king. The great king... ///

3 /// ... [a servant] by the name of Tarmatāse [is given]. This Tarmatāse... royal...

4 /// but he was not working because of ...Now, this Tarmatasse intended to give(?) two thousand $k_{u}$ śānes as a yearly (amount) to(?) the Yurpāṣka

5 /// ...[was... season... he showed]... by (giving a) mercy. By honouring me, (namely) [Puttatāse,... Tarmatāse $]. .$.

b

$1 / / /$...people... five... Thus it shall be as it is written(?) above in this document. Forever in the future... ///

2 /// ...Sankkaiśe the Okau-official announced. Su-? [wrote].

SI 6456 (= SI Strelkov-D/85)

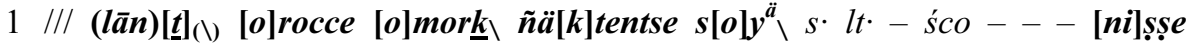
șamāne ///

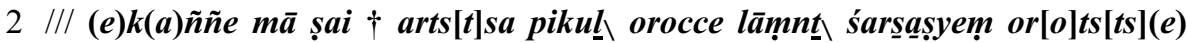
walo ekita ///

$3 / / /$ (ma)ñiye pretạn $\backslash$ tarmatāse ñem $\backslash$ se [ta]rmatāse lantaññana (p)re ///

$4 / / /$ [ña]ke se tarma[t]āse ///

$1 / / /$...(the great) [king] (of Kucha), son of the great Omork* god/majesty,... //

2 /// ...it was not a possession... Each year, they informed the great king. The great king... help... ///

3 /// ... a servant by the name of Tarmatāse is given. This Tarmatāse... royal...

4 /// Now, this Tarmatāse... ///

There is no trace of writing on the verso of SI 6456; hence, the lower part of its contents would have been written on another tablet that has been lost.

The ductus of THT4063 and SI 6456 are standard. Generally, their language can be dated to the classical stage. ${ }^{50}$ The spelling $<\underline{\text { śca }}>$ in THT4063b1 can be dated to both archaic and classical stages, ${ }^{51}$ but this faint akșara may also be read as $[s] c \underline{a}$. Therefore, precisely dating THT4063 and SI 6456 is still impossible. Moreover, determining whether SI 6456 is a straightforward duplicate of THT4063 or vice versa is difficult. A safer interpretation is to view both as annual reports written in different years and submitted to the royal house or some responsible officers. At any rate, the

\footnotetext{
${ }^{50}$ For example, wiltse 'two thousand' in THT4063a4 is classical according to Peyrot (2008: 128-129, 184).

${ }^{51}$ For a discussion of $<\underline{\text { śca }}>$, cf. PEYROT 2008: 179-180.
} 
dates of these two tablets are not far from each other because the same person Tarmatasse is mentioned in both. They are very probably older than the seventh-century wooden laissez-passers found by Pelliot.

\section{Conclusion}

In this paper, we give our reading and interpretation of the thus-far unedited tablets SI 3656 (SI P/136в), 3669 (SI Р/139д), 6385 (SI Strelkov-D/3), 1931 (SI Strelkov-D/51) and 6456 (SI Strelkov-D/85). Among them, SI 3656, 3669 and 6385 attest the name of Yurpasska. They are good examples to indicate the significance of the Russian Collection for the study of human geography in the western regions of China.

SI 3656 is especially valuable to scholars because it reveals the practice of copying formulae from old documents to make new ones. As far as can be seen, SI 3656 is likely a certification of change of identity. It seems to have been a necessary document for the novice Punyayase and his partner to settle in the Yurpasșa Monastery, which was located around the Kizil grottoes.

The practice of making documents by copying formulae from old documents or a model text is further implied by SI 6456 and THT4063, both of which belong to a series of yearly reports to Kuchean kings. Given that it is about the same person Tarmatāse, these two tablets were possibly issued by the same group of staff. Because THT4063 was unearthed from the Kizil grottes, SI 6456 is also likely to be from the same site. Infrared photography will be indispensable to compare the two tablets thoroughly.

SI 1931 is another important piece. The severely damaged text proves that three currencies, $k_{u}$ śāne* 'Kuchean coins', cāne* '(Chinese?) coins' and tinā $r^{*}$ 'gold coins', circulated in Kucha simultaneously at a certain historical period before the Tang Conquest.

In conclusion, the wooden documents kept in the IOM, RAS are essential first-hand materials to study Buddhist sites in the Kucha region. Their connection to the Berlin collection invites scholars to continue tracing the activities of Russian and German expeditions in Chinese Turkestan in the early twentieth century. 


\section{Glossary}

The transcribed forms are used here in the place of the transliterated ones. (PN for personal name; exclamation marks for damaged attestations).

\begin{tabular}{|c|c|c|c|}
\hline Akeñe & 'of the Frontier' & m.sg.nom. akeñe & SI 3669a4, b2 \\
\hline Agamadhāre & 'Āgama-holder' & sg.nom. Agamadhāre & SI $3656 b 2 !$ \\
\hline Arañ̃̃e & 'forest-dweller, ascetic' & sg.nom. Ārañye & SI 3656b2 \\
\hline artstsa & 'each' & & $\begin{array}{l}\text { SI 6456.2; } \\
\text { THT4063a2 }\end{array}$ \\
\hline allek & 'other' & m.sg.gen. ālyekepi & SI 3656a9 \\
\hline Atsiñe & 'of $* \bar{A} t s i$ ' & m.sg.nom. Atsiñe & SI 3669a4 \\
\hline $\bar{a} k s-$ & 'to announce' & 3sg.prt. ākșa & THT4063b2 \\
\hline \multirow{2}{*}{ Ābhidhārmike } & \multicolumn{3}{|c|}{ 'one learned in the abhidhārma' } \\
\hline & & sg.nom. Ābhidhārmike & SI 3656b1! \\
\hline $\bar{a}$ yor & 'gift, donation' & sg.obl. āyor & SI $3656 a 8$ \\
\hline \multirow[t]{2}{*}{ emṣketstse } & 'even, unto' & emșketstse & THT4063b1 \\
\hline & & enșketse & SI $3656 a 8$ \\
\hline \multirow[t]{2}{*}{ ekañ̃̃e } & 'possession' & sg.nom. ekaṃñ̃̃e & THT4063a2 \\
\hline & & sg.nom. ekaññe & SI 6456.2 \\
\hline ekalymi & 'subject to' & ekälymī & $\begin{array}{l}\text { SI 3656a4! } \\
\text { (or: ekälymi) }\end{array}$ \\
\hline ekito* & 'help' & sg.obl. ekita & SI $6456.2 !$ \\
\hline ekșalye & 'season' & pl.obl. ekșalyim & THT4063a5! \\
\hline eneśne & 'in cash' (for accounting & lit. 'in one's eyes') & SI 1931(a)3! \\
\hline eñcil & 'imposed' & sg.nom./obl. eñcil & SI 6385(a)1 \\
\hline \multirow[t]{2}{*}{$a i-$} & 'to give' & 3sg.opt. $\bar{a} y i$ & SI 3656a7! \\
\hline & & inf. aitsi & SI $6385(\mathrm{a}) 2$ ! \\
\hline omșamem & '(from) above' & & THT4063b1 \\
\hline \multirow[t]{3}{*}{ Okau } & Official title/position & nom. Okau & SI 6385(b)1; \\
\hline & & & THT4063b2 \\
\hline & & nom. $\mathrm{Oko}_{u}$ & SI 3656a6 \\
\hline \multirow[t]{2}{*}{ Omork* } & '?' & obl. Omork & SI 6456.1; \\
\hline & & & THT4063a1 \\
\hline ompek & 'right there' & & SI 6385(a)2 \\
\hline \multirow[t]{3}{*}{ orotstse } & 'great, big' & m.sg.nom. orotstse & SI 6456.2; \\
\hline & & & THT4063a2! \\
\hline & & m.sg.obl. orocce & SI 6456.1, 2; \\
\hline
\end{tabular}




\begin{tabular}{|c|c|c|c|}
\hline \multicolumn{2}{|c|}{ Kapä $[r c] \ddot{a}[t] \bar{a} y[\mathrm{PN}]$} & \multirow{2}{*}{$\begin{array}{l}\text { nom. Kapä }[r c] \ddot{a}[t] \bar{a} y \\
\text { sg.nom. kalya }\end{array}$} & \multirow{2}{*}{$\begin{array}{l}\text { SI } 3669 b 5 \\
\text { SI } 6385(b) 2 !\end{array}$} \\
\hline kalya & Official title/position(?) & & \\
\hline \multirow[t]{2}{*}{ kärs- } & 'to inform (K.)' & 3.pl.impf. śarsäșyem & THT4063a2 \\
\hline & & 3.pl.impf. śarsäșyem & SI 6456.2 \\
\hline$K \ddot{a} w[o] t \operatorname{siñ} e^{*}$ & 'of $K \ddot{a} w[o] t s i$ ' & m.sg.obl. Käw[o]tsiñe & SI $3669 b 1$ \\
\hline \multirow[t]{3}{*}{$k_{u} s^{\prime} \bar{a} n e^{*}$} & 'Kuchean coin' & pl.nom. $k_{u} s \dot{a} a n i$ & SI 1931(a)3!, (b)2! \\
\hline & & pl.obl. $k_{u} s \dot{a} n e m$ & THT4063a4 \\
\hline & & 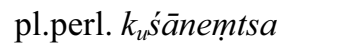 & SI 6385(a)3! \\
\hline$k_{l \imath}$ śiññe $^{\prime}$ & Kuchean, of Kucha' & m.sg.obl. $k_{l}$ śiññe & THT4063a1 \\
\hline ketara & 'to whomever' & & SI 3656a9! \\
\hline kettrā & 'to whomever' & & SI $3656 a 4$ \\
\hline \multirow[t]{2}{*}{ kșum * } & 'reign' & sg.perl. kșuṃtsa & SI 3669a1! \\
\hline & & sg.loc. kṣuṃne & SI 3669a1! \\
\hline \multirow[t]{2}{*}{$k s a$} & indef.pron. & gen. ketara & SI $3656 \mathrm{a} 9$ \\
\hline & & gen.: kettrā & SI $3656 \mathrm{a} 4$ \\
\hline cāne* & 'coin' & pl.obl. cānem & SI 1931(a)4, 5! \\
\hline cämp- & 'to be able to' & 3.pl.prs. cimmpem & SI $6385(a) 3$ ! \\
\hline \multirow[t]{2}{*}{ ñake } & 'now' & & SI 6456.4; \\
\hline & & & THT4063a4 \\
\hline \multirow[t]{2}{*}{ ñakte } & 'god' & sg.gen. ñäktentse & SI 6456.1; \\
\hline & & & THT4063a1 \\
\hline \multirow[t]{5}{*}{$\tilde{n} \ddot{a} s$} & 'I' & sg.gen. $\tilde{n} i$ & THT4063a5 \\
\hline & & du.nom. wene & SI 3656a4, 6, 7 \\
\hline & & pl.nom. wes & SI $3656 a 4$ \\
\hline & & pl.nom. wesä & SI 6385(a)2 \\
\hline & & pl.gen. wesäñ & SI $3656 a 7,10$ \\
\hline ñäsk- & 'to demand' & Ger.I.m.pl.nom. ñäșșalyi & SI $3656 a 9$ \\
\hline \multirow[t]{4}{*}{ nem* } & 'name' & sg.obl. ñem & SI 3656a3; \\
\hline & & & $3669 \mathrm{a} 3 !$ \\
\hline & & & 6385(a)3; 6456.3; \\
\hline & & & THT4063a3 \\
\hline ta & 'then' & & THT4063a4 \\
\hline \multirow[t]{2}{*}{ Tarmatāse $[\mathrm{PN}]$} & < Skt. Dharmadāsa- & nom. Tarmatāse & SI $6456.3,3,4 !$ \\
\hline & & & ТНT4063a3, 3,4 ! \\
\hline$t a ̈ n k w-\ddot{a} \tilde{n} \tilde{n}-$ & 'to love' & Abstr.perl.: tänkwalyesa & THT4063a5! \\
\hline tärk- & 'let go; allow, etc.' & 3sg.prt. tärkāte & SI 3669a3 \\
\hline $\operatorname{tin} \bar{a} r^{*}$ & 'gold coin' & pl.nom. tināränta & SI 1931(b)2 \\
\hline
\end{tabular}




\begin{tabular}{|c|c|c|c|}
\hline \multirow[t]{6}{*}{ nes- } & \multirow[t]{6}{*}{ 'to be' } & inf.loc. nestsine & SI $3656 a 7$ \\
\hline & & 3sg.impf. șai & SI 6456.2; \\
\hline & & & THT4063a2, 5 \\
\hline & & 3sg.opt. tākoy & THT4063b1 \\
\hline & & 3sg.opt. $t \bar{a} k o_{i}$ & SI 3656a9!, 10 \\
\hline & & 3pl.prt. takare & SI 6385(b)1 \\
\hline \multicolumn{2}{|l|}{ Nañissțe [PN] } & nom. Nañīṣte & SI 3669a4 \\
\hline no & 'but' & & SI 3656a7 \\
\hline nowcot & 'deposit(?)’ & & SI 6385(b)2! \\
\hline patalakșa* & '? (proper name?)' & sg.loc. patalakșane & SI 6385(a)2 \\
\hline \multirow[t]{2}{*}{ parso } & 'document' & sg.perl. pärsosa & SI 3656a8 \\
\hline & & sg.loc. parsone & THT4063b1 \\
\hline \multicolumn{2}{|l|}{ Palkeśe [PN] } & nom. Palkeśe & SI 6385(a)3! \\
\hline päk- & 'to intend' & 3sg.prt. pkāte & THT4063a4 \\
\hline \multirow[t]{2}{*}{ pär- } & 'to carry' & 3sg.prs.(?) pretär & $\begin{array}{l}\text { SI 6456.3; } \\
\text { THT4063a3 }\end{array}$ \\
\hline & & 3pl.prt. kamānte & SI 1931(a)4! \\
\hline pärk- & 'to ask' & Ger.I.m.pl.nom. prekșalyi & SI 3656a9 \\
\hline pälsk- & 'to think' & 1pl.prt. pälskamo & SI $3656 a 6$ \\
\hline \multirow[t]{3}{*}{ pik- } & 'to write' & 3sg.prt. paika & THT4063b2! \\
\hline & & 3pl.prt. paikānte & SI 1931(a)4 \\
\hline & & prt.part.m.sg.nom. papekau & THT4063b1 \\
\hline pikul & ‘year' & sg.obl. pikul & $\begin{array}{l}\text { SI } 6456.2 ; \\
\text { THT4063a2 }\end{array}$ \\
\hline \multirow{3}{*}{$\begin{array}{l}\text { pikulșe } \\
\text { piś } \\
\text { piśältse }\end{array}$} & 'prting to a year' & m.pl.obl.pikulșem & THT4063a4 \\
\hline & 'five' & & THT4063b1(pī́s) \\
\hline & 'five thousands' & & SI 6385(a)3 \\
\hline \multicolumn{2}{|c|}{ Pūñyavräddhi $[\mathrm{PN}]<$ Skt. Punyavṛddhi- } & nom. Pūñyavräddhi & SI $3656 b 2$ \\
\hline \multirow{2}{*}{\multicolumn{2}{|c|}{ Punyayaśe $[\mathrm{PN}]<$ Skt. Punyayaśas }} & nom. Puṇyayaśe & SI $3656 a 3$ \\
\hline & & gen. Punyayaśi & SI 3656b1! \\
\hline \multirow{2}{*}{\multicolumn{2}{|c|}{$\begin{array}{l}\text { Puttatāse* }[\mathrm{PN}]<\text { Skt. Buddhadāsa- } \\
\text { Purnāáśä }[\mathrm{PN}]\end{array}$}} & gen. Puttatāsi & THT4063a5 \\
\hline & & nom. Purṇāśä & SI 3669a3 \\
\hline \multicolumn{2}{|c|}{ Purnakke* $[\mathrm{PN}]$} & gen. Purnakki & SI 3669b2 \\
\hline \multirow{2}{*}{\multicolumn{2}{|c|}{$\begin{array}{l}\text { Purnakșeme }[\mathrm{PN}]<\text { Skt. Pūrnakșema- } \\
\text { paikāntsa* ‘ } \pm \text { painter, calligrapher’ }\end{array}$}} & nom. Purnakșeme & SI 3669b2 \\
\hline & & pl.nom. paiykāntsaṃ & SI 1931(a)4! \\
\hline postanu & 'later, latter' & m.sg.obl. postanontä & SI 1931(a)2 \\
\hline postañ̃̃e & 'later' & m.sg.obl. postañ̃ne & $\begin{array}{l}\text { SI } 3656 \mathrm{a} 8 \\
\text { THT4063b1 }\end{array}$ \\
\hline
\end{tabular}




\begin{tabular}{|c|c|c|c|}
\hline \multirow[t]{2}{*}{ preke } & \multirow[t]{2}{*}{ 'time' } & sg.obl. preke & $\begin{array}{l}\text { SI 3656a1!, 8; } \\
3669 \mathrm{a} 2\end{array}$ \\
\hline & & sg.abl. prekemem & SI 3656b1! \\
\hline procer & 'brother' & sg.nom. procer & SI 3669b2 \\
\hline plāce & 'word, speech' & sg.obl. placä & SI $3656 a 6$ \\
\hline mañiye & 'servant' & sg.nom. mañiye & $\begin{array}{l}\text { SI 6456.3; } \\
\text { THT4063a3 }\end{array}$ \\
\hline mant & ‘so’' & mamt & SI $3656 \mathrm{a} 4,6$ \\
\hline & & mäntak & THT4063b1 \\
\hline$m \bar{a}$ & 'not' & $m \bar{a}$ & $\begin{array}{l}\text { SI 6456.2; } \\
\text { THT4063a2, } 4\end{array}$ \\
\hline & & $m a$ & SI $3656 a 9,9$ \\
\hline mānäkke* & '?' & sg.com. mānäkkempā & SI $3656 a 6$ \\
\hline mäkte & 'as' & mäkte & THT4063b1 \\
\hline mäktse & & & SI 3656a9! \\
\hline mäsk- & 'to be' & prs.part. mäskeñcā & SI $3656 a 3$ \\
\hline & & prs.part. mäskeñca & SI 3669a2 \\
\hline$m i-$ & 'to harm' & 3pl.prs. miyäskemmme & SI $3656 a 5$ \\
\hline Yaśotarko* $[\mathrm{PN}$ & & gen. Yaśotarkontse & SI 3669b1 \\
\hline yām- & 'to do' & 3pl.prs. yamaskenme & SI $3656 a 5$ \\
\hline & & 3sg.prt. yamaṣa & SI 6385(b)1 \\
\hline & & prt.part.f.pl.nom. yāmwa & SI 3656a2! \\
\hline yärs- & 'to honor' & Abstr.I.perl.: yärșalñesa & THT4063a5 \\
\hline Yurpāṣka & Name of monastery & nom. Yurpașka & SI 6385(a)2! \\
\hline & & nom. Yurpāṣka & THT4063a2!, 4! \\
\hline & & obl. Yurpāṣkai & SI 3669a2! \\
\hline & & Yūrpașk. & SI 3656a2! \\
\hline$y[u] s a$ & '?' & & SI 1391(a)5 \\
\hline yoniyatse & 'of yoniya' & m.sg.nom. yoniyatse & SI 3669b4 \\
\hline Ypoy-moko & $' \pm$ Prefect' & sg.nom. Ypoy-moko & SI 3669a4 \\
\hline reme & 'witness' & pl.nom. remi & SI 6385(b)1 \\
\hline lakle & 'pain' & sg.obl. lakle & SI $3656 a 5$ \\
\hline lantañ̃̃e* & 'royal' & f.pl.nom./obl. lantañ̃̃ana & $\begin{array}{l}\text { SI 6456.3; } \\
\text { THT4063a3 }\end{array}$ \\
\hline Larașke [PN] & & nom. Larașke & SI 3669b1! \\
\hline lāṃs- & 'to work' & 3sg.impf. lamsșitär & ТНT4063a4 \\
\hline lip- & 'remain, be left over' & 3pl.prt. lyipāre & SI 1931(b)1! \\
\hline
\end{tabular}




\begin{tabular}{|c|c|c|c|}
\hline \multirow[t]{4}{*}{ walo } & 'king' & sg.nom. walo & $\begin{array}{l}\text { SI 6456.2; } \\
\text { THT4063a2 }\end{array}$ \\
\hline & & sg.obl. lānt & $\begin{array}{l}\text { SI 6456.1; } \\
\text { THT4063a1, 1, } 2\end{array}$ \\
\hline & & sg.obl. lāmnnt & SI 6456.2 \\
\hline & & sg.gen. lānte & SI 3669a1 \\
\hline waste & 'refuge' & sg.nom. waste & SI $3656 \mathrm{a} 10$ \\
\hline \multirow{3}{*}{$\begin{array}{l}\text { wäntare } \\
\text { wäs- } \\
\text { wiltse }\end{array}$} & 'affair' & sg.perl. wantäresa & SI 6385(b)3 \\
\hline & 'to dwell' & 3sg.impf. wsaṣi & SI 3656a6 \\
\hline & 'two thousand' & & THT4063a4 \\
\hline \multirow{2}{*}{$\begin{array}{l}\text { we- } \\
\text { Wrau }[\mathrm{PN}]\end{array}$} & 'to tell' & 1pl.prs. weskem & SI $3656 a 8$ \\
\hline & & nom. Wrau & SI 6385(b)2! \\
\hline \multirow{2}{*}{$\begin{array}{l}\text { śakk șe } \\
\text { śamaśke }\end{array}$} & 'eleven' & & SI 3669a1! \\
\hline & 'boy' & sg.obl. śamaśkem & SI 3669a3! \\
\hline \multirow{2}{*}{\multicolumn{2}{|c|}{ Śiñcake [PN] }} & sg.gen.: śamaśkeṃtse & SI 3669b5! \\
\hline & & nom. Śiñcake & SI 3669b4 \\
\hline śaumo & 'person, man' & pl.nom./obl. śāmna & THT4063b1 \\
\hline șañ ā̃̃m & '(one)self' & șañ āñmo & SI $3656 a 7$ \\
\hline șanmire & 'novice monk' & sg.nom. șanmire & SI $3656 a 3$ \\
\hline șamāne & 'monk' & sg.nom. șamāne & SI $6456.1 !$ \\
\hline șarm & 'cause' & sg.perl. șarmtsa & SI $3656 a 6$ \\
\hline \multicolumn{2}{|c|}{ Ștakule [PN] } & nom. Ștakule & SI $3669 b 3$ \\
\hline spä & 'and' & $s p$ & THT4063a4 \\
\hline \multicolumn{2}{|c|}{ Șletaś [Official title] } & sg.nom. Șletaś & SI 6385(b)2 \\
\hline \multirow[t]{2}{*}{ san்kārām } & 'monastery' & sg.obl. san்kārāmä & SI $3656 a 2,10 !$ \\
\hline & & sg.obl. sān்kārāmäa & SI 3656a7 \\
\hline \multicolumn{2}{|c|}{ Sañkaiśe [PN] } & nom. Sañkaiśe & THT4063b2 \\
\hline \multicolumn{2}{|c|}{ Sankkule [PN] } & nom. San்kule & SI 6385(b)1! \\
\hline san்krām & 'monastery' & sg.loc. saìkrāmne & $\begin{array}{l}\text { SI 3656a9; } \\
3669 \mathrm{a} 2\end{array}$ \\
\hline$s \bar{a} \dot{n} k$ & '(monastic) community' & sg.obl. sāìnkä & SI $3656 \mathrm{a} 7$ \\
\hline sälk- & 'to show' & 3sg.prt. salka & THT4063a5 \\
\hline $\operatorname{sim}$ & 'bundary, limit' & sg.nom./obl. sim & SI 1931(a)5 \\
\hline \multirow[t]{4}{*}{ su } & dem.pron. & m.sg.obl. $c e_{u}$ & $\begin{array}{l}\text { SI 3656a1, 2, 6!, } \\
7,9, \text { b1, } 4\end{array}$ \\
\hline & & m.sg.obl. cauw & SI $3669 \mathrm{a} 2 !$ \\
\hline & & n.sg.obl. $t u$ & SI 6385(a)2 \\
\hline & & n.sg.gen. tuṃtse & SI 3669a3! \\
\hline
\end{tabular}




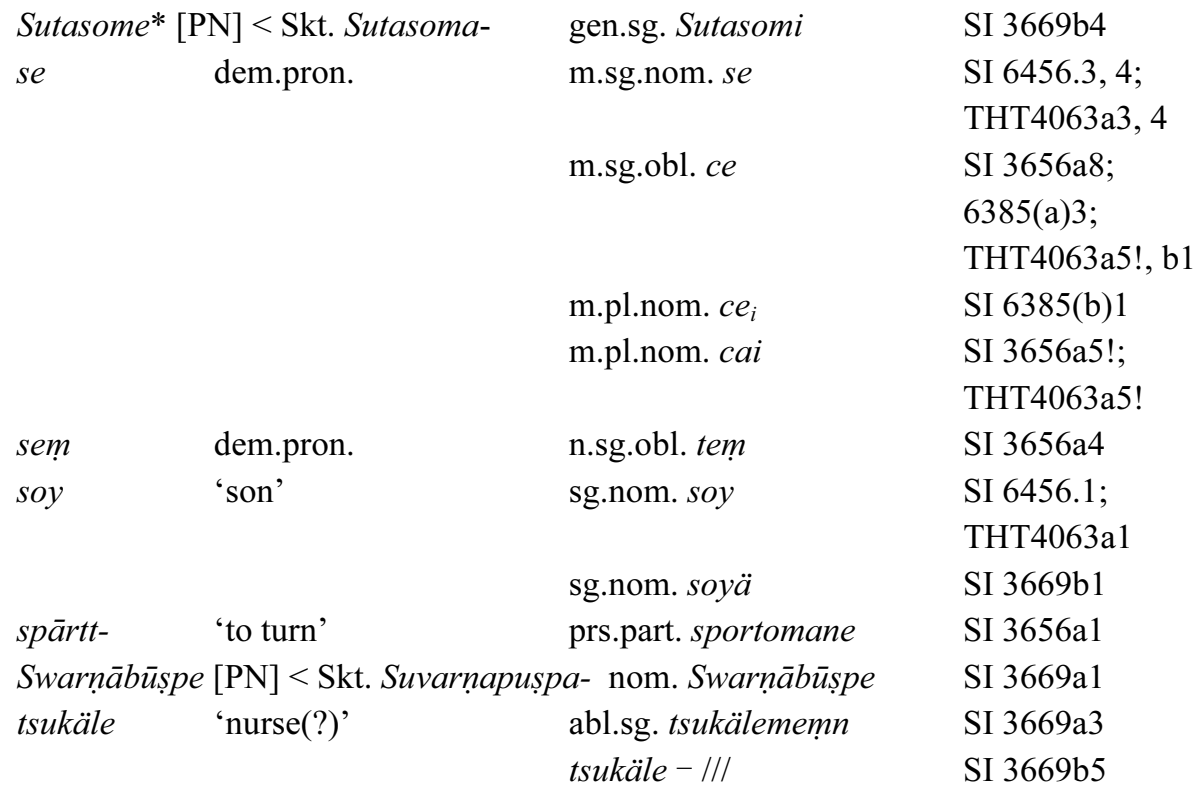

\section{References}

ADAMS, Douglas Q. 1999: A Dictionary of Tocharian B. Amsterdam: Rodopi.

ADAms, Douglas Q. 2000: "Some Observations of Peoples, Places, and Languages in the Tarim Basin in the First Millennuim AD”. Tocharian and Indo-European Studies, 9 (2000), $1-28$.

ADAms, Douglas Q. 2013: A Dictionary of Tocharian B. Revised and Greatly Enlarged. Amsterdam: Rodopi.

Bongard-Levin G.M. and Lardinois, Roland and Vigasin A.A. 2002: Correspondances Orientalistes entre Paris et Saint-Pétersbourg (1887-1935). Paris: De Boccard.

ChIng Chao-jung 2010: Secular Documents in Tocharian: Buddhist Economy and Society in the Kucha Region. Dissertation thesis, École Pratique des Haute Études.

CHING Chao-jung 2013a: "Reanalyzing the Kuchean-Prākrit tablets THT4059, THT4062 and SI P/141". Tocharian and the Indo-European Studies, 14 (2013), 55-94. (= Ching 2013a)

CHING Chao-jung 慶昭蓉 2013b: “Cong Qiuciyu tongxing xukezheng kan ru Tang qianhou zhi Xiyu jiaotong 從龜茲語通行許可證看入唐前後之西域交通” [Traffic in the Western Regions before and after the Tang Conquest: A Reflection on the Kuchean laissez-passers]. Xiyu Wenshi 西域文史 [Literature \& History of the Western Regions], vol. 8 (2013). Ed. by Zhu Yuqi 朱玉麒. Peking: Science Press, 65-83.

CHING Chao-jung forthcoming: "Communications between Russian and French Scholars in the Early 20th Century on Tocharian B Secular Documents". Proceedings of the Sergey Fedorovich Oldenburg: Scholar and Academic Research Organizer International conference devoted to the 150th anniversary of Academician S.F. Oldenburg. Ed. by I.F. Popova. Moscow: Vostochnaya literatura. 
Ching Chao-jung and Oginara Hirotoshi 2010: "Internal Relationships and the Dating of the Tocharian B Monastic Accounts in the Berlin Collection". Nairiku Ajia gengo no kenkyu [Studies on the Inner Asian Languages], 25 (2010), 75-142.

CHING Chao-jung and OGIHARA Hirotoshi 2012: "A Tocharian B Sale Contract on a Wooden Tablet”. Journal of Inner Asian Art and Archaeology 5 (2010[2012]), 101-128.

LÉvi, Sylvain 1913: "Le «Tokharien B», langue de Koutcha". Journal Asiatique, 11e série, vol. 2 (1913), 311-380.

Malzahn, Melanie 2007a: "Tocharian Texts and Where to Find them". Instrumenta Tocharica. Ed. by M. Malzahn. Heidelberg: Winter, 79-112.

MALZAHN, Melanie 2007b: "The Most Archaic Manuscripts of Tocharian B and the Varieties of the Tocharian B Language". Instrumenta Tocharica. Ed. by M. Malzahn. Heidelberg: Winter, 255-297.

MironOv N.D. 1909: "Iz rukopisnykh materialov ekspeditsii M.M. Berezovskogo v Kuchu". Bulletin de l'Académie Impériale des Sciences de St. Pétersbourg, 8 (1909), 547-562.

OGIHARA Hirotoshi 2009: Researches about Vinaya-texts in Tocharian A and B. Dissertation thesis, École Pratique des Haute Études.

OGIHARA Hirotoshi 荻原裕敏 2013: “Lüelun Qiuci shiku xiancun gudaiqi Qiuciyu tiji 略論龜 兹石窟現存古代期龜兹語題記” [On the Kuchean Archaic Inscriptions Surviving in the Grottoes in the Region of Kucha]. Dunhuang Tulufan yanjiu 敦煌吐鲁番研究 [Journal of the Dunhuang and Turfan Studies], 13 (2013), 371-386.

Peyrot, Michaël 2008: Variation and Change in Tocharian B. Amsterdam: Rodopi.

PINAULT, Georges-Jean 1998: "Economic and Administrative Documents in Tocharian B from the Berezovsky and Petrovsky Collections". Manuscripta Orientalia, vol. 4, no. 4 (1998), 3-20.

PINAUlT, Georges-Jean 2002a: "Tocharian and Indo-Iranian: Relations between Two Linguistic Areas". Indo-Iranian Languages and Peoples. Ed. by N. Sims-Williams. Oxford: Oxford University Press, 243-284.

PinAUlT, Georges-Jean 2002b: “Toch. B k $\mathrm{u}_{\mathrm{u}}$ caññe, A $\mathrm{k}_{\mathrm{u}}$ cim et skr. tokharica". Indo-Iranian Journal, 45 (2002), 310-345.

PINAULT, Georges-Jean 2008. Chrestomathie tokharienne. Textes et grammaire. Leuven-Paris: Peeters.

Popova I.F. 2008a: "Russian Expeditions to Central Asia at the Turn of the 20th century". Russian Expeditions to Central Asia at the Turn of the 20th Century. Ed. by I.F. Popova, St. Petersburg: Slavia, 11-39.

PopOVA I.F. 2008b: "S.F. Oldenburg's First Russian Turkestan Expedition (1909-1910)". Russian Expeditions to Central Asia at the Turn of the 20th Century. Ed. by I.F. Popova, St. Petersburg: Slavia, $148-157$.

SCHMIDT, Klaus 2001a: "Zeitenwende an der Seidenstrasse. Zur Sprachgeschichte des Westtocharischen nach der Schlacht von To-ho (648 n. Chr.)". Tempus edax rerum, le bicentenaire de la Bibliothèque nationale de Luxembourg (1798-1998). Ed. By Luc Deitz. Luxembourg: Bibliothèque nationale de Luxembourg, 151-162.

SCHMIDT, Klaus 2001b: "Entzifferung verschollener Schriften und Sprachen Dargestellt am Beispiel der Kučā-Kharoșțh̄̄ Typ B und des Kučā-Prākrits”. Göttinger Beiträge zur Asienforschung, 1 (2001), 7-27.

SCHMIDT, Klaus 2002: "Bemerkungen zum Einleitungsteil des osttocharischen Maitreyasamitināțaka". In: Splitter aus der Gegend von Turfan, Festschrift für Peter Zieme anläßlich 
seines 60. Geburtstags. Ed. by Mehmet Ölmez and Simone-Christiane Raschmann. Istanbul-Berlin: M. Ölmez, 257-264 (Türk Dilleri Araştırmaları Dizisi 35).

SEIPEL, Wilfried 1996: Weihrauch und Seide. Alte Kulturen der Seidenstraße. Wien: Wasmuth Ernst.

Thomas, Werner. Tocharisches Elementarbuch. Band II. Heidelberg: Winter, 1964.

VOROBIOV-DESIATOVSKII V.S. 1958: "Pamiatniki central'noaziatskoi pis'mennosti” [Texts in Central Asian writing]. Uchionye zapiski Instituta Vostokovekeniia [Proccedings of the Institute of Oriental Studies], 16 (1958), 280-308.

Vorobiova-DesiatovsKaia M.I. 1907: "The Ancient Manuscripts from Eastern Turkestan in the St. Petersburg". Tocharian and Indo-European Studies, 7 (1997), 205-212.

Vorobiova-Desiatovskaia M.I. 2004: "The Role of N.F. Petrovsky in the Formation of the Central Asiatic Manuscript Collection of the St. Petersburg Branch of the Institute of Oriental Studies". In: Turfan Revisited - The First Century of Research into the Arts and Cultures of the Silk Road. Berlin. Ed. by D. Durkin-Meisterernst, S.-C. Raschmann, J. Wilkens, M. Yaldiz and P. Zieme. Berlin: Dietrich Reimer, 361-362.

Vorobiova-DesiatovsKaia M.I. 2006: "The Central Asian Manuscript Collection of the St. Petersburg Branch of the Institute of Oriental Studies of the Russian Academy of Sciences". Annual Report of the International Research Institute for Advanced Buddhology at Soka University, 9 (2006), 61-78.

Vorobiova-Desiatovskaia M.I. 2008: “M.M. Berezovsky's Expedition to Kucha (19051908)". In: Russian Expeditions to Central Asia at the Turn of the 20th Century. Ed. by I.F. Popova, St. Petersburg: Slavia, 65-74.

WINTER, Werner 1963: “Tocharians and Turks". Uralic and Altaic Studies, 23 (1963), 239251.

Xinjiang Kucha Academy 新疆龜茲研究院, Center for Research on Ancient Chinese History, Peking University 北京大學中國古代史研究中心, Institute for Historical and Philological Studies of China's Western Regions, School of Chinese Classics, Renmin University of China 中國人民大學國學院西域歷史語言研究所 2013a: “Kezi’er shiku houshanqu xiancun Qiuciyu ji qita Polomi wenzi tiji neirong jianbao (I) 克孜爾石窟後山區現存龜茲 語及其他婆羅謎文字題記內容簡報(一)” [A Brief Report of the Back Mountain District of the Kizil Grottoes, Part I]. Dunhuang Tulufan yanjiu 敦煌吐鲁番研究 [Journal of the Dunhuang and Turfan Studies], 13 (2013), 341-369.

Xinjiang Kucha Academy 新疆尧茲研究院, Institute for Historical and Philological Studies of China's Western Regions, School of Chinese Classics, Renmin University of China 中 國人民大學國學院西域歷史語言研究所, Center for Research on Ancient Chinese History, Peking University 北京大學中國古代史研究中心 2013b: “Xinjiang Baicheng Yixiakegou shiku diaocha jianbo 新疆拜城亦狹克溝石窟調查簡報” [The survey of the Ishak Valley Grottoes in Baicheng County, Xinjiang]. Wenwu 文物 [Cultural Relics], 2013, issue 12, 56-66.

Taishō: 大正新脩大蔵經 Taishō shinshū daizōkyō [Taishō Revised Tripitaka]. Ed. by Takakusu Junjirō 高楠順次郎. Tokyo: Taishō Issaikyō Kankōkai 大正一切經刊行會, 1924-1934. 